\title{
Tanier (Xanthosoma spp.) propagation in vitro ${ }^{1,2}$
}

\author{
Lii-Jang Liu, Evelyn Rosa-Márquez, \\ Margarita Licha and Maria L. Biascoecheas
}

\begin{abstract}
The standard medium for in vitro propagation of taniers (Xanthosoma sagittifolium and $X$. violaceum) was improved by supplementing Murashige and Skoog's basic formula (MS) with $2 \mathrm{mg} / \mathrm{l}$ glycine, $5 \mathrm{mg} / \mathrm{L}$ indoleacetic acid (IAA), 2 mg/L kinetin and $10 \%$ coconut water (v/v). Gamborg's $B_{5}$ medium was found better than Abo-Zettler (AZ) and MS media for callus formation. Clorox $10 \%$ for 10 minules, Clorox $5 \%$ for 5 minutes and Clorox $1 \%$ for 1 to 2 minutes consecutively was the best combination for surface sterilization. Bactericides, actidione $0.02 \%$ and sodium azide $1 / 40$ were ineffective. Protoplasts of approximately $4 \times 10^{5}$ per $\mathrm{ml}$ were isolated and calcium oxalate crystals were eliminated with the modified Binding fechniques. Data obtained from two replicated field trials at the Gurabo Agricultural Experiment Station indicated that the average weight of corms from apparently healthy tanier plants was significantly $(P<.01)$ more than that of corms from plants with dasheen mosaic virus symptoms. Similarly, the average weight of corms produced by tanier plants free from the symptoms of "mal seco" disease was significantly $(P<.01)$ more than that of corms obtained from plants affected by the disease. Variations in shape and size of the leaves as well as in dasheen mosaic virus symptoms among the plantlets are described.
\end{abstract}

\section{RESUMEN}

Propagación in vitro de la yautía (Xanthosoma spp.)

Los nutrimentos glicina (2 mg./l.), Geido indolacético (IAA, $5 \mathrm{mg} . / \mathrm{l}$.), cinetina (2 mg./1.) y agua de coco $(10 \%, v / v)$ mejoraron grandemente la propagación de yautías (Xanthosoma sagittifolium y $X$. violaceum) in vitro al incorporarse al medio basal Murashige \& Skoog (MS). El medio de Gamborg (B-5) fue mejor para desarrollar callos que el medio de Abo-Zettler (AZ) y el MS. El método más eficaz para esterilizar la superfieie del tejido fue Clorox al $10 \%$ por 10 minutos, $5 \%$ por 5 minutos y $1 \%$ por 1 a 2 minutos. Los bactericidas actidiona $0.02 \%$ y azida sódica $(1 ; 40)$ para esferilizar no fueron eficaces. Se aislaron aproximadamente $4 \times 10^{5}$ protoplastos por $\mathrm{ml}$. Se eliminaron los cristales de oxalato de calcio usando la téenica de Binding. El peso medio de los cormos de las plantas sanas fue mayor $(\mathrm{P}<0.01)$ que el de las plantas con virus del mosaico de la malanga (dasheen mosaic virus-DMV). El peso medio de los cormos de las plantas libres de mal seco fue mayor que el de las plantas enfermas. Se describen

'Manuscript submitted to Editorial Board 8 October 1987.

'This study was part of the investigation supported by USDA Cooperative Agreement No. 58-7880-9-115 (TAD Research Grant).

aPlant Pathologist and Research Assistants, Agricultural Experiment Station, University of Puerto Rico, Mayagüez Campus, Río Piedras, P. R. 00928. 


\section{variaciones en forma y tamaño de las hojas y la expresión de los síntomas del virus del mosaico de la malanga.}

\section{INTRODUCTION}

The farm value of the tanier (Xanthosoma spp.) crop reached $\$ 5.3$ million in 1986 (3). Tanier production has decreased recently because of high incidence of "mal seco" disease and possibly dasheen mosaic virus. The application of meristem culture methods to vegetatively propagated plants such as tanier has become increasingly important because pathogen-free stock plants can be generated, maintained and increased with relative ease. From 1974-1980, several investigators $(1,11,26)$ initiated in vitro culture of Colocasia and Xanthosoma in Florida and California. In 1980, Licha et al. (14) initiated in Puerto Rico meristem culture and induced callus and shoot development of taniers. Variations in morphology and dasheen mosaic virus symptoms in tanier plantlets derived from callus culture were also reported $(15,16,17)$. While working in this laboratory in 1985, Gupta described similar morphological variations and culture media for callus induction and plant regeneration of Xanthosoma (10). Difficulties are frequently eneountered by growers who want to establish meristem culture of taniers in Puerto Rico because of the lack of comprehensive data on culture media, sources of materials used as well as sterilization techniques. This paper describes the methods developed in this laboratory for in vitro callus induction, shoot differentiation and protoplast isolation in taniers. The average weight of corms observed under field conditions from both apparently healthy tanier plants and those with dasheen mosaic virus or "mal seco" disease symptoms are also compared statistically.

\section{MATERIALS AND METHODS}

The corms of Xanthosoma sagittifolium cv. Blanca del País and $X$. violaceum cv. Morada (Vinola) used in this study were obtained from the Corozal Agricultural Experiment Station. Shoot tips were sterilized in $10 \%$ Clorox for 10 minutes, followed by 2 to 3 washings with sterile distilled water containing $0.1 \%$ ascorbic acid. Outer layers of the sterilized shoot tips were removed under a dissecting microscope in the laminar flow. The meristematic domes bearing 3 leaf primordia $(0.2$ to $0.4 \mathrm{~mm}$ long) were cut out and cultured on various culture media.

Studies were made in the attempt to determine the effect of culture media on callus formation and growth of tanier, disinfectants on surface sterilization, bactericides and fungicides on contamination, and plant growth regulators on callus induction and shoot differentiation.

For the culture media study, the following 6 substrates were evaluated: a) Murashige and Skoog's medium (21) with $20 \mathrm{~g} / \mathrm{L}$ sucrose, 1 $\mathrm{g} / \mathrm{L}$ myo-inositol and $1 \mathrm{p} / \mathrm{m}$ 2,4-dichlorophenoxyacetic acid (2,4-D); b) re- 


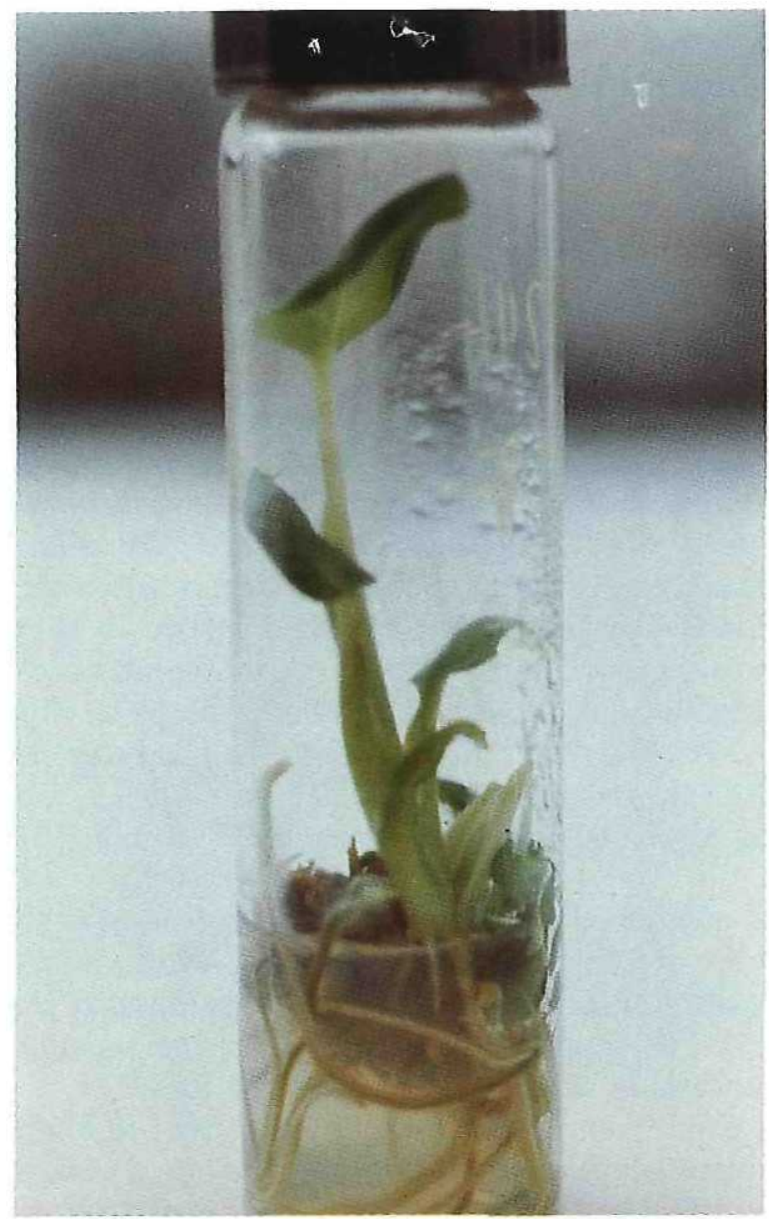

Fig. 1.-Disease-free plantlet of tanier (Xanthosoma sp.) via meristem-tip culture (test tube stage).

vised tobacco medium with vitamins and increased sugar ( $5 \mathrm{~g} / \mathrm{L}$ myo-inositol, $30 \mathrm{~g} / \mathrm{L}$ sucrose) and $1 \mathrm{mg} / \mathrm{L} 2,4-\mathrm{D}$; c) Murashige and Skoog's medium plus increased sugar, no 2,4-D, but modified by adding (i) glycine, indoleacetic acid and 6-furfuryl amino purine (kinetin) and (ii) casein, naphthaleneacetic acid (NAA) and kinetin; d) Murashige and Skoog plus increased sugars (5 g/L myo-inositol, $20 \mathrm{~g} / \mathrm{L}$ sucrose, $10 \mathrm{~g} / \mathrm{L}$ glucose) and $1 \mathrm{mg} / \mathrm{L}$ 2,4-D; e) AZ (1) medium; and (f) Gamborg's $\mathrm{B}_{5}$ medium (9).

For the study on surface sterilization, the following 4 methods were evaluated: $70 \%$ alcohol for $1 \mathrm{~min}, 10 \%$ Clorox for $1 \mathrm{~min}$; $70 \%$ alcohol for $1 \mathrm{~min}, 2 \%$ Clorox for $15 \mathrm{~min}$; 3\% Lysol for $1 \mathrm{~min}$, $70 \%$ alcohol for $1 \mathrm{~min}$, 
$2 \%$ Clorox for $15 \mathrm{~min}$; and $10 \%$ Clorox for $10 \mathrm{~min}, 5 \%$ Clorox for $5 \mathrm{~min}$, $1 \%$ Clorox for 1 to $2 \mathrm{~min}$, and by rinsing them afterwards 3 times with double-distilled sterile water.

For the study on protoplast isolation, plantlets previously incubated at $27^{\circ} \mathrm{C}, 380$ footcandle light intensity and $16 \mathrm{~h}$ photoperiod were transferred to a dark chamber for 24 to $72 \mathrm{~h}$, and subsequently used for isolating protoplasts. Approximately 2 to $5 \mathrm{~g}$ of leaf tissue were sterilized $3 \mathrm{~min}$ with $10 \%$ Clorox and Tween $80(1 \mathrm{drop} / 25 \mathrm{ml})$ solution and rinsed 3 times with autoclaved distilled water. The sterilized leaf tissue was cut with a sterile scalpel and the resulting materials filtered through a 120 $\mu$ filter. After filtration, the fine pieces of leaf tissues were suspended overnight ( 15 to $17 \mathrm{~h}$ ) in an enzyme solution consisting of $0.25 \%$ cellulase, $0.25 \%$ macerozyme, and $0.6 \mathrm{M}$ mannitol. The suspension was adjusted to $\mathrm{pH} 5.8$ with $0.1 \mathrm{~N} \mathrm{NaOH}$, diluted with seawater (730 millimol), poured into test tubes and centrifuged 3 times at $1,000 \mathrm{r} / \mathrm{m}$. After centrifugation, the seawater in the suspension was replaced with a $0.6 \mathrm{M}$ sucrose solution. As soon as the seawater was replaced, protoplasts rose to the surface of the sucrose solution forming a green band at the upper level of the test tubes. These floating protoplasts in the band were isolated with a fine pipette, cultured in parafilm sealed petri dishes containing the liquid medium V-47 $(4,5)$, and incubated at $22^{\circ} \mathrm{C}$ under 15 footcandle light.

The above-mentioned procedure was a modification of the Binding's method $(4,5)$ for protoplast isolation. Ricardo Alfonso's method (2) for protoplast isolation was also tried. The Alfonso method consisted of a lower speed of centrifugation $(700 \mathrm{r} / \mathrm{m})$ than the modified Binding's method and a washing solution as described by Kao (13).

Two field experiments were established in 1981 at the Gurabo Agricultural Experiment Station to determine the effect of dasheen mosaic virus on corm weight and the effect of "mal seco" disease on corm weight.

For the study on the effect of dasheen mosaic virus on yield of corms, variety Blanca del País was selected. A total of 1,116 plantlets derived from meristem culture of taniers were used. Half were inoculated mechanically with the dasheen mosaic virus by the method of Monllor et al. (20) and the other half were not inoculated. The inoculated plantlets showing the dasheen mosaic virus symptoms were planted in the field for comparison with the non-inoculated plantlets (presumably mosaicfree). The weights of corms were recorded.

For the study on the effect of "mal seco" on yield of corms, an equal number of plantlets were planted in the area heavily infested by the disease. On the basis of symptoms produced, plantlets were divided into 2 groups: the apparently healthy and the "mal seco" affected plants. They were planted in 24 plots. Corm weights were recorded. 


\section{RESULTS}

Effect of culture media on callus formation and plant regeneration

of the 6 different culture media tested, Gamborg's $B_{5}$ medium (9) was found better than all the other media for callus induction. With this medium, calluses were induced 6 weeks after culturing. There were no significant differences in callus formation between varieties Blanea del País and Vinola. Callus formation seemed to be faster in the dark than in light. The effect of various hormones and amino acids on plant regeneration was also studied. The MS medium containing $2 \mathrm{mg} / \mathrm{L}$ glycine, 5 $\mathrm{mg} / \mathrm{L}$ IAA and $2 \mathrm{mg} / \mathrm{L}$ kinetin plus $10 \%$ coconut water $(\mathrm{v} / \mathrm{v})$ appeared to be the best for shoot differentiation and proliferation (fig. 1).

Effect of disinfectants on surface sterilization

None of the 4 different combinations of disinfectants involving alcohol and Clorox was better than surface sterilization consisting of 3 changes in Clorox ( $10 \%$ for $10 \mathrm{~min}, 5 \%$ for $5 \mathrm{~min}$ and $1 \%$ for $2 \mathrm{~min}$ ). The combination of alcohol with Clorox did not yield satisfactory results, nor Lysol with Clorox.

Effect of bactericides and fungicides on contamination

Actidione at $0.02 \%$ and sodium azide at $1 / 40$ were added to the Murashige and Skoog (21) and AZ (1) media. Neither was effective for controlling surface contamination.

Protoplast isolation

Binding's method $(4,5)$ as modified by us consists of a) $1,000 \mathrm{r} / \mathrm{m}$ centrifugation, b) 730 millimol seawater as washing solution and c) overnight (15-17 h) enzyme solution treatment for leaf materials. This modified method was found better for tanier protoplast isolation than other methods and combinations of methods. A large number of protoplasts (4 $\times 10^{5} / \mathrm{ml}$ ) were obtained, and at the same time calcium oxalate crystals were eliminated (fig. 2 and 3). The protoplasts were cultured in V-47 medium $(4,5)$. Divisions beyond the single-protoplast stage were observed (fig. 4).

\section{Yield trials}

The two field experiments which had been established in 1981 at the Gurabo Substation were harvested in 1982. The corms from apparently healthy tanier plants derived from meristem cultures were significantly $(\mathrm{P}<.01)$ heavier than those of corms from plants with dasheen mosaic virus symptoms. Figure 5 shows that the average weight of corms from the plants free from the symptoms of dasheen mosaic virus ranged from 0.3 to $0.7 \mathrm{~kg}$, whereas the average weight of corms from the plants affected by the virus ranged from 0.1 to $0.3 \mathrm{~kg}$. The affected plants also 


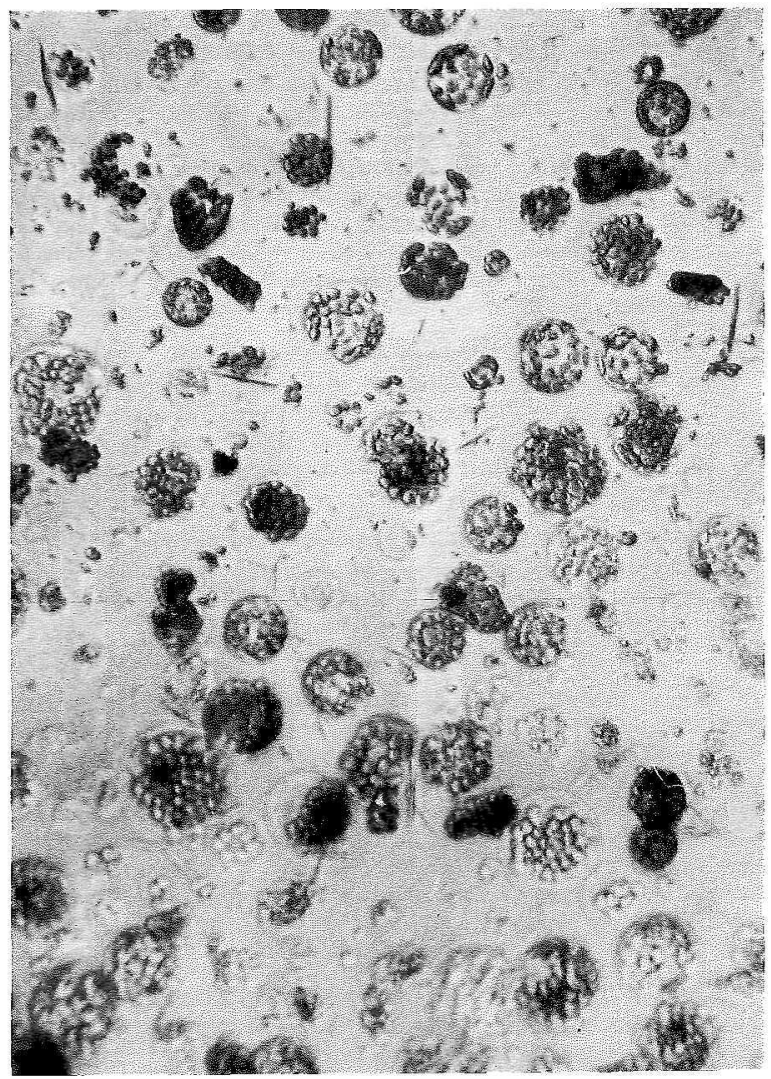

FIG. 2.-Protoplasts from the leaves of Xanthosoma sagittifolium (note the presence of calcium oxalate erystals). 


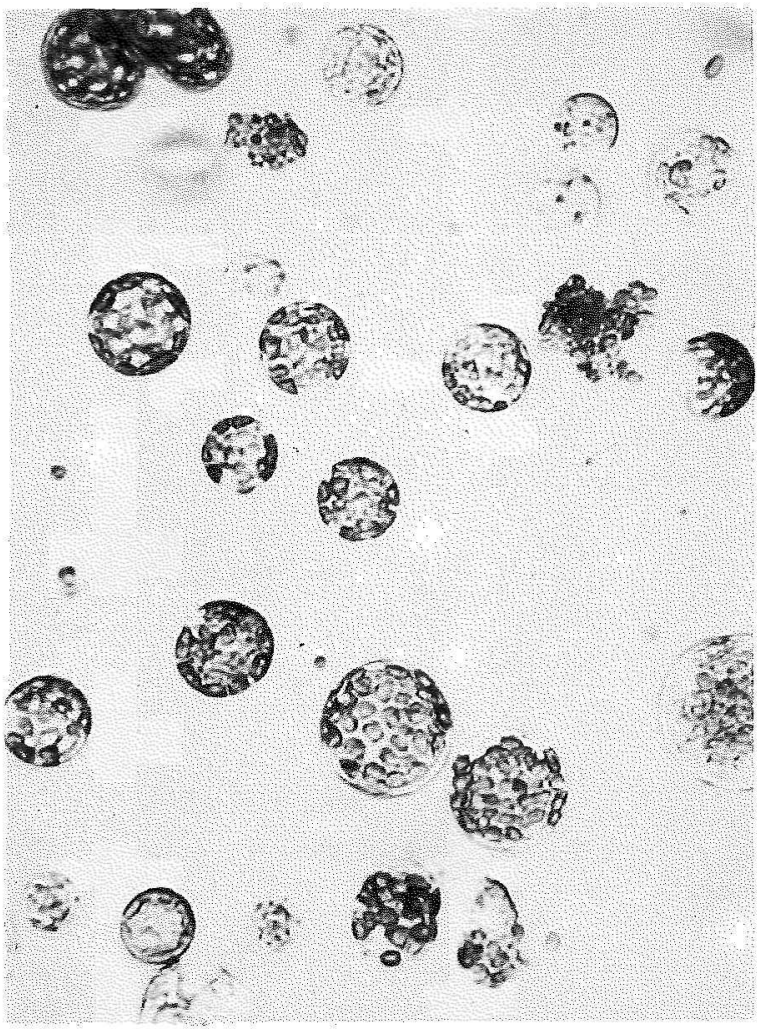

FIG. 3.-Protoplasts isolated from the leaves of Xanthosoma sagittifolium (note the absence of the ealcium oxalate crystals). 


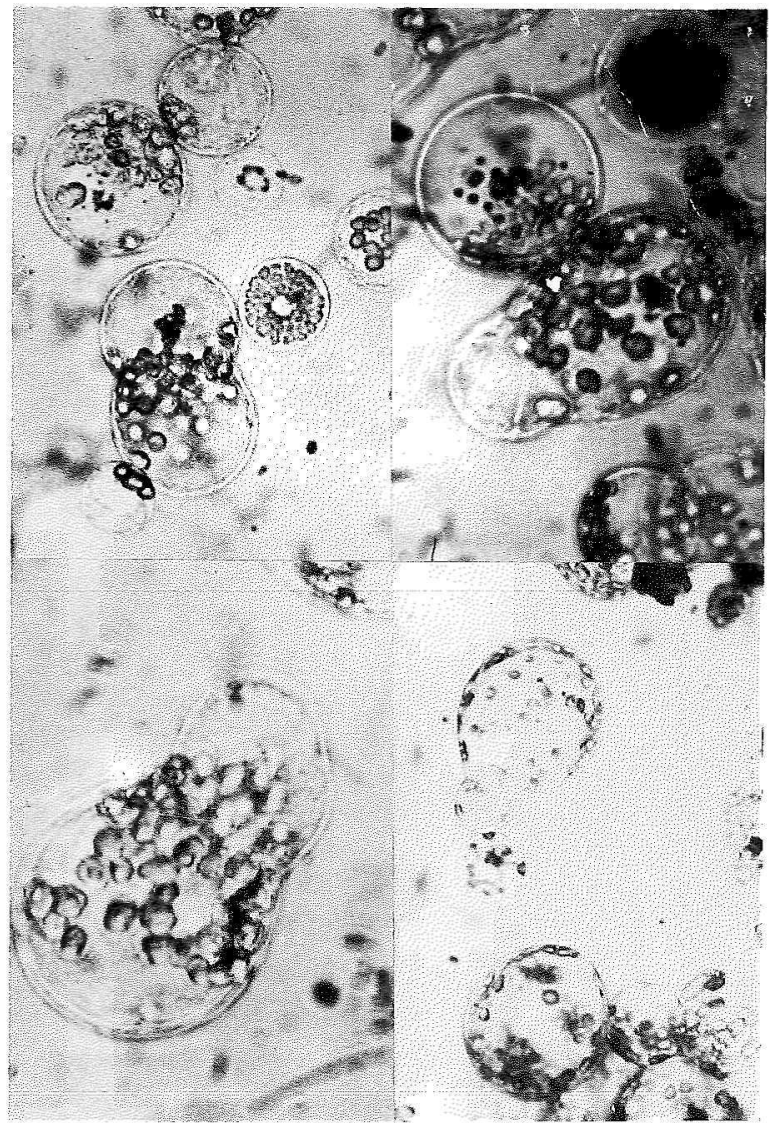

FIG. 4.-Protoplasts of tanier in the culture medium V-47 (note the elongation and division of the protoplasts). 
J. Agric. Univ. P.R. voL. 72, No. 3, JULY, 1988

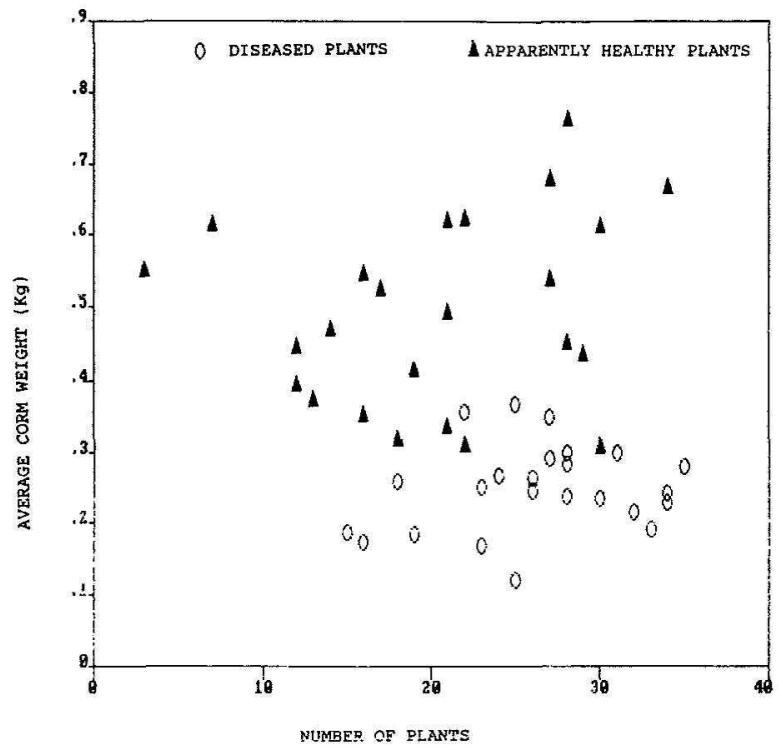

FIG. 5.-Average corm weight of apparently healthy (meristem culture) and dasheen mosaic virus-affected plants of Xanthosoma sagittifolium.

showed a general discoloration and depressed growth. In addition to the morphological variations (narrow elongated leaves, figure 6), we also observed variations in disease symptoms (mottling, vein chlorosis, feathery and malformation (fig. 7)).

Similarly, the corms from the apparently healthy taniers (free from the "mal seco") were significantly $(P<1.01)$ heavier than those of corms from plants affected by the "mal seco". The average weight of corms from the apparently healthy taniers ranged from 0.2 to $1.0 \mathrm{~kg}$, whereas those of corms from "mal seco" affected taniers ranged from 0.2 to 0.5 $\mathrm{kg}$ (fig. 8).

\section{DISCUSSION}

Successful induction of calluses and shoots in taniers depends upon a number of factors, such as sources of materials and culture media as well 


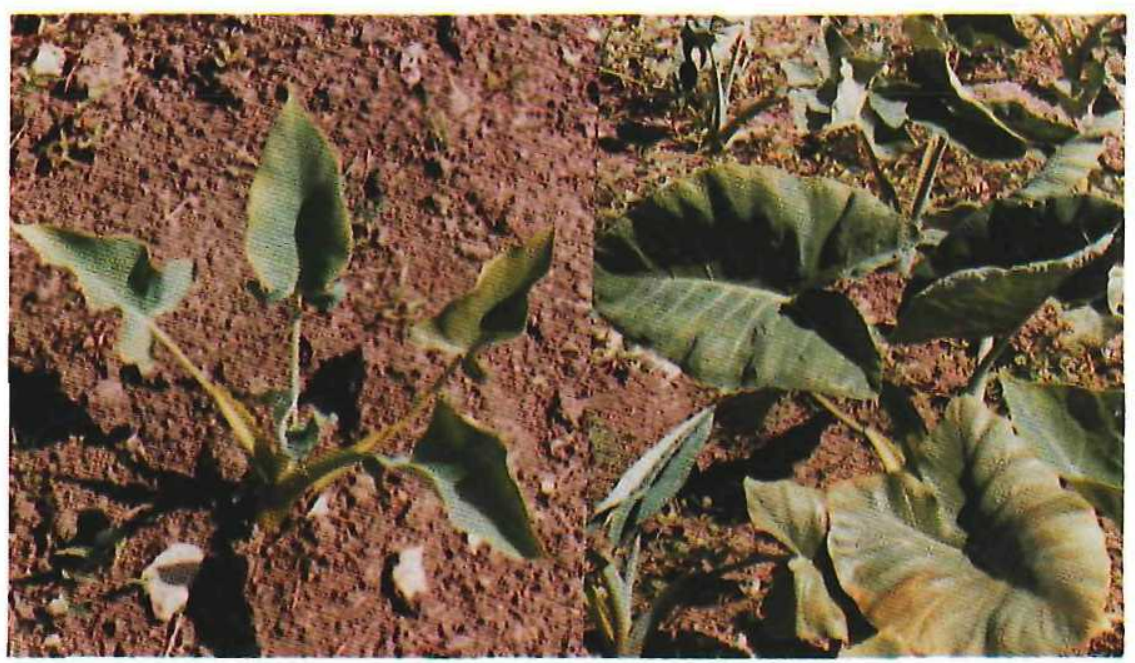

FIG. 6.-Variations in shape of leaves among plants of Xanthosoma sagittifolium derived from tissue culture.

as disinfection techniques. In general, high concentration of auxin and low concentration of cytokinins promote callus formation. On the contrary, high concentration of cytokinin and low concentration of hormones, especially 2,4-D, promotes shoot differentiation. The results obtained in this study indicated that Gamborg's $B_{5}$ medium (9) with high concentration of salts stimulates callus formation in taniers. It was found better than the AS medium (1) which was favored by other investigators (10).

The Murashige and Skoog medium (21), containing $20 \mathrm{mg} / \mathrm{L}$ glycine, $5 \mathrm{mg} / \mathrm{L}$ indoleacetic acid and $2.0 \mathrm{mg} / \mathrm{L}$ kinetin, appeared to be the best for shoot differentiation and proliferation.

Careful peeling of the leaves surrounding the meristem dome under aseptic conditions should keep the explants considerably free from contamination. In order to assure a maximum sterilization with minimum adverse effect on explant tissues or lateral buds, two or three changes of Clorox are needed. Clorox at $10 \%$ for $10 \mathrm{~min}, 5 \%$ for $5-30 \mathrm{~min}$ and $1 \%$ for 1 to 3 min with continuous agitation has been adopted as a routine procedure for tanier surface sterilization. Preconditioning the plants under aseptic conditions would also help to reduce some of the contamination and oxidation problems.

The size and condition of the explants should also be taken into consideration. The smaller the size of the explant, the shorter the time it needs for sterilization. Clorox and alcohol were found to be ideal disinfectants for surface sterilization of taniers. Bactericides, such as actidione and 


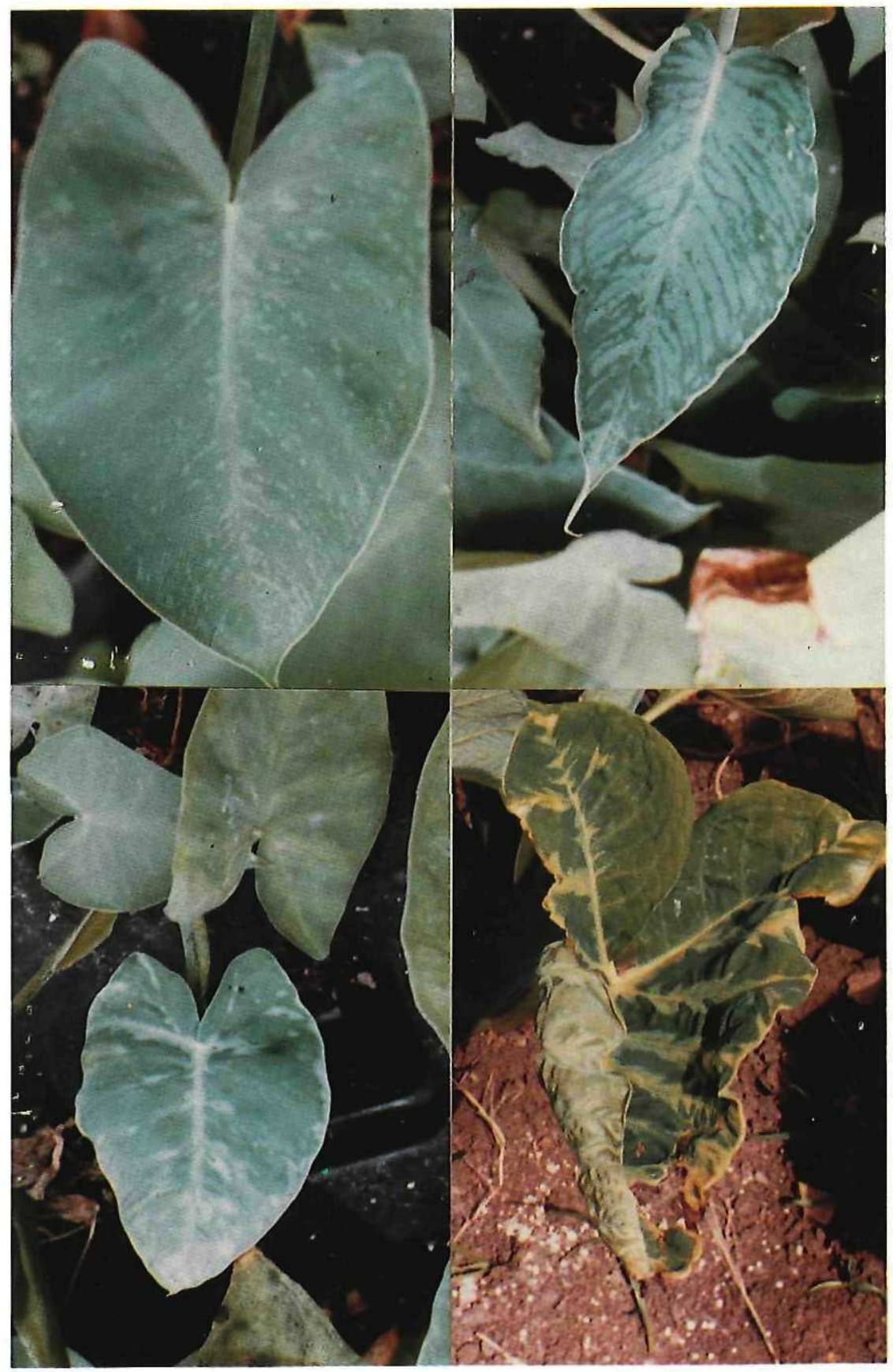

FIG. 7.-Variations in dasheen mosaic virus symptoms among plantlets of Xanthosoma sagittifolium derived from tissue culture. (Upper left: mottling and upper right: vein chlorosis. Lower left: feathery and lower right: malformation). 


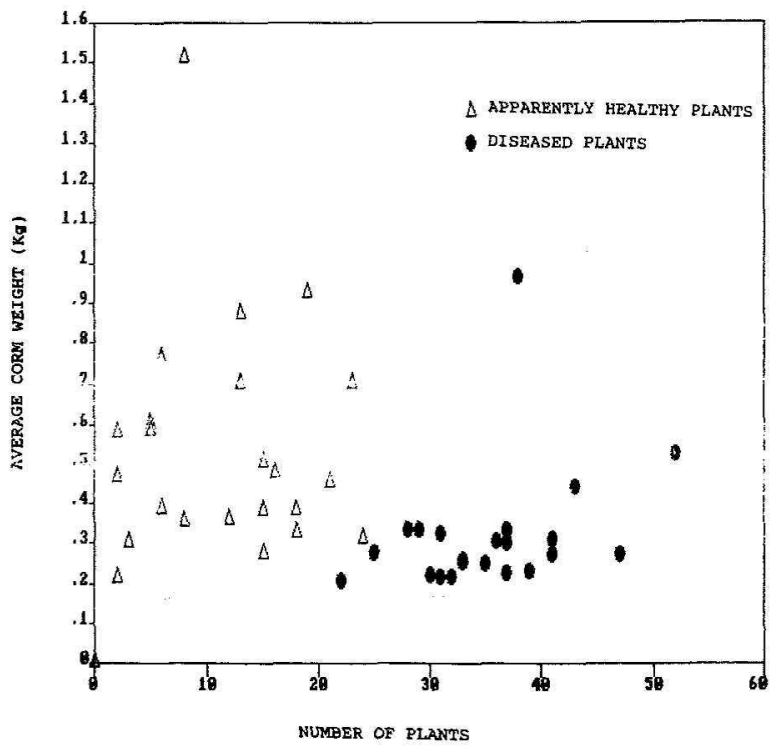

FIG. 8,-Average corm weight of apparently healthy (meristem culture) and "mal seco" diseased plants of Xanthosoma sagittifolium.

sodium azide, as well as fungicides such as mercuric chloride, were found to be inadequate for surface sterilization of taniers.

Protoplasts have been isolated from Datura (24), Daucus (8), Nicotiana $(19,25,27)$, Petunia $(22,27)$, rice $(6,7)$, corn $(21,22)$, and sugarcane (18). However, isolation of protoplasts from monocotyledonous plants such as tanier is a difficult task. Sugar and inorganic salts are known to influence cell regeneration and sustain division in plant protoplasts $(12,18)$. With additional sugar and salts, Binding's V-47 medium $(4,5)$ would probably sustain cell division better.

Yield increase obtained in this study should be of great interest to local growers because it provides evidence to indicate that quality of seeds may play an important role in commercial production of taniers in Puerto Rico. The variability in morphology as well as in disease 
symptoms in the population of tissue culture taniers as observed in this study would also encourage plant breeders to use this technique for selecting clones resistant to "mal seco" and dasheen mosaic virus.

\section{LITERATURE CITED}

1. Abo-El Nil, M. M. and F. W. Zettler, 1981. Callus initiation and organ differentiution from shoot tip cultures of Colocasia esculenta. Plant Sci. Lett, 6: 401-08.

2. Alfonso-Torres, Rieardo L., 1981. Fusion of protoplasts isolated from homozygous sulphur mutant (su/su) and crown gall cell of Nicotiana tabacum. Master thesis from the Dept. of Biology, University of Puerto Rico, Mayagüez Campus.

3. Annonimous, 1986. Situación de la Empresa de Farináceas en Puerto Ríco. Dept. Ècon. Agrice, Esta. Exp. Agríc., Rio Piedras, P. R.

4. Binding, H., 1974. Regeneration von haploiden und diploiden Planzen aus Protoplasten von Peturia hybrida L. Z. Pflanzentphysiol. 74: 327-56.

5. - 1974. Fusions vercuche mit isoliesten protoplasten von Petamia hybrida L. $Z$. Pflanzenphysiol. 72, 421-26.

6. Cai, O., Y. Quian, Y. Shou and S. Wui, 1978. A further sturly on the isolation and culture of rice (Oryza sativa L.) protoplasts. Acta Bot. Sinica 20: 97-103.

7. Deka, P. C. and S. K. Sen, 1976. Differentiation in calli originated from isolated protoplasts of rice (Oryza sativa L.) through plating teehnique. Mol. Gen. Genet. 145: $239-43$.

8. Dudits, D., G. Hadlaczky, E. Levi, O. Feger, Z. Haydu and G. Lazer, 1977. Somatic hybridization of Daucus canota and $D$. capillifolius by protoplast fusion. Theor. Appl. Genet. 51: 127-32.

9. Gamborg, O. L., R. A. Miller and K. Ojima, 1968. Plant cell cultures. I. Nutrient requirements of suspension cultures of soybean root cells, Exp. Cell Res. 50; 151-58.

10. Gupta, P. P., 1985. Plant regeneration and variabilities from tissue cultures of cocoyams (Xanthosoma sagittifolitum and $X$. violacoum). Plant Cell Rep. 4: 88-91.

11. Hartman, R. D., 1974. Dasheen mosaic virus and other phytopathogens eliminated from caladium, taro and cocoyams by culture of shoot tips. Phytopathology 64: 23740.

12. Kao, K. N., 1975. A method for fusion of plant protoplasts with polyethylene glycol. In: Plant Tissue Culture Methods (O. L. Gamborg and L. R. Wetter, Eds), pp. 22-7. Nat. Res. Council of Canada, Saskatoon.

13. Kao, K. N., O. L. Gamborg, M. R. Michayluk, W. A. Keller and R. A. Miller, 1973. The effects of stgar and inorganic salts on cell regeneration and sustained division in plant protoplasts. Colloq. Int. C, N.R. S., Paris 212: 207-13.

14. Licha, M., D. Baella and L. J. Liu, 1980. Effect of various media in callus formation, proliferation and plantlet development in taniers. Phytopathology 72 (1): 171.

15. Liu, L. J., M. Licha, D. Baella and E. Rosa-Márquez, 1982. Variation in morphology and mosaic virus resistance in plantlets of taniers (Xanthosoma spp.) via tissue culture. Phytopathology 72 (7): 990.

16. —_- E. Rosa-Márquez, M. Licha and M. L. Biascochea, 1983. Isolation and culture of callus and protoplasts of taniers (Xanthosoma spp.) in Puerto Rico. Phytopathology 73 (5): 791.

17. — - and M. L. Biascochea, 1983. Tanier tissue culture in Puerto Rico. Proc. XIX Caribbean Food Crops Society, Mayagiez, P. R., p. 280.

18. Maretzki, A. and L. G. Nickell, 1973. Formation of protoplasts from sugarcane cell suspensions and the regeneration of cell cultures from protoplasts. Colloq. Int. C. N. R. S. Paris 212: 151-63. 
19. Melchers, G. and G. Labid, 1974. Somatic hybridization of plants by fusion of protoplasts. I. Selection of light resistant hybrids of "haploid" light sensitive varieties of tobacco. Molec. Gen. Genet. 135: 277-94,

20. Monllor, A. C., J. Escudero, J. Bird, F. W. Zettler and L. J. Liu, 1986. Virus diseases of taniers in Puerto Rico and the Dominican Republic. Proc. Tropieal/Subtropical Res. Symposium, Gainesville, Florida 111: 41-50.

21. Murashige, T. and F. Skoog, 1962. A revised medium for rapid growth and bioassays with tobaceo tissue culture. Physiol. Plont. 15: 473-97.

22. Portrykus, I. C., T. Harans, H. Lorz and E. Thomas, 1977. Callus formation from stem protoplasts of corn (Zea mays L.). Molec. Gen. Genet. 156: 347-50.

23. Power, J, B., E, M. Frearson, C. Hayward, D. George, P. K. Evans, S. F. Berry and E. C. Cocking, 1976. Somatic hybridization of Petunia hytrida and P. Parodii. Nature, London 263: 500-02.

24. Schieder, O., 1978. Somatic hybrids of Datura innoxia Mill. + Datura discolor Bernh. and of Datura innovia Mill. + Datura stramonium L. var. tatula L. Molec. Gen. Genet. 162: 113-19.

25. Smith, H, H., K. N. Kao and N. C. Combatti, 1976. Interspecific hybridization by protoplast fusion in Nicotiana. Confirmation and extension. J. Hered. 67: 123-28.

26. Strauss, M. S. and J. Arditti, 1980. Plantlet regeneration from shoot tip eultures of Xanthosoma caracu. Ann. Bot. 45; 209-12.

27. Vasil, V. and $J$. K. Vasil, 1974. Regeneration of tobaeco and petunia plants from protoplasts and culture of eorn protoplasts. In Vitro 10: 83-96. 